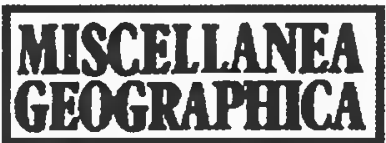

Vol. 122006 pp. 95-101

Małgorzata Bogucka, Artur Magnuszewski

Department of Hydrology

E-mail: asmagnus@uw.edu.pl

\title{
THE SEDIMENTATION PROCESSES IN WEOCEAWEK RESERVOIR
}

\begin{abstract}
The study discusses accumulation and erosion processes which occurred in the bowl of Wlocławek Reservoir in the period 1971-1992, and were analysed using digital batimetric maps. It also provides the results of the work of other authors concerning the assessment of the river sediments accumulated in the reservoir.

Analysis of digital batimetric maps has shown that the material deposited in Wloclawek Reservoir in the years 1971-1992 totalled about 18.3 million $\mathrm{m}^{3}$, which corresponds to approximately 0.87 million $\mathrm{m}^{3}$ of sediments per annum, and means a $4.5 \%$ loss of the reservoir's storage capacity. The volume of accumulation and erosion, assessed in this manner, approximates the earlier calculations performed using different research methods; it corroborates the fact that accumulation prevails in the balance of the sediments.
\end{abstract}

Key words: GIS techniques, sedimentation, dam reservoir, the Vistula River, Wloclawek Reservoir

\section{INTRODUCTION}

A water reservoir created as a result of damming the river leads to an intensified accumulation of alluvial deposits carried by the water. This phenomenon has serious consequences, as it results in a gradual shrinking of the reservoir's storage capacity, which in turn reduces its role in the economy. It is generally assumed that if the storage capacity of a dam reservoir decreases by $75-80 \%$ as compared to the initial capacity, the economic usefulness of the reservoir is practically nonexistent (Głodek, 1985). For this reasons, assessing the speed of siltation processes is so important in view of the planned functions of the reservoir.

\section{PURPOSE OF RESEARCH}

The research project was aimed at indicating the area of Włocławek Reservoir prevailing erosion or accumulation. In addition to that, the volumes of the accumulated and eroded sediments were calculated. 
Created in 1970, Włocławek Reservoir has an area of approximately $70.4 \mathrm{~km}^{2}$, with a total storage capacity of 408 million $\mathrm{m}^{3}$. At a normal storage level, the Reservoir covers the river section from 618 to $674,850 \mathrm{~km}$ (Babiński, Grześ, 1995). It is a typical river reservoir, long and narrow, with a relatively straightforward coastline, and a backcurve of over $58 \mathrm{~km}$, reaching beyond the city of Płock (Ankiersztajn, 2002).

\section{RESEARCH METHOD}

The research was based on digital balance maps, created by comparing hypsometric maps of the bottom of Włocławek Reservoir for the years 1971, 1984 and 1992. The data needed for their preparation originated from the maps of the bed forms on the 1:10 000 scale, which were obtained through an interpolation of the bottom ordinates from transversal cross-sections.

The river bed cross-section charts were prepared by "Hydroprojekt", a Włocławek-based company, on the basis of the depth echosoundings, taken in Włocławek Reservoir using an echosounder linked to a radar rangefinder (Śliwiński, 1992). The measurements were taken along 81 sections, covering the main river bed, with small parts of the floodplain on both river banks. The distances between individual sections ranged between 300 and $800 \mathrm{~m}$ (Śliwiński, 1979). The results from all the transversal cross-section soundings taken in the years 1971, 1984 and 1992 were used in the research.

The ordinates of the river bed from the transversal cross-sections were transposed onto a 1:10 000 topographic map of the Vistula river, which where then digitised using the ILWIS software. The intersections of the one-kilometre grid were used as control points in map registration, with the coordinates provided in metres (according to the 1942 system).

To obtain raster maps showing a digital model of the bottom with a spatial resolution of $5 \times 5 \mathrm{~m}$, the kriging interpolation was used, as it gives best results when used in hypsometric maps.

Raster maps allow for a comparison of the bottom ordinates' values from three different years because every single pixel represents a corresponding value of the altitude above sea-level (Fig.1., Fig. 2.). As a result of substracting the values of two raster maps, we obtained a final raster image, showing the differences in the bottom ordinates for every point (Fig. 3.).

On the basis of such maps, histograms were prepared using the ILWIS software, in which a given value of accumulation or erosion was attributed to every single raster point. Also, information about the area covered by rasters with identical values was provided. These data were transposed into Excel. Then, individual erosion and accumulation areas were aggregated; the volumes of accumulated and eroded materials were also calculated. The calculations were made for three periods: 1971-1984, 1984-1992, and 19711992. 


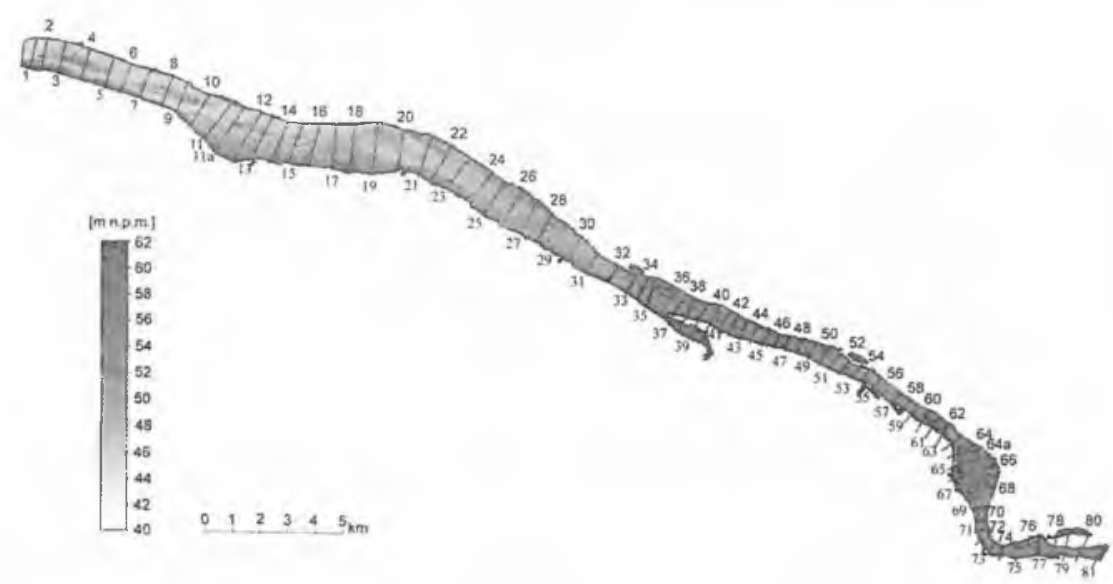

Fig. 1. Ordinates of the bottom of Włocławek Reservoir in 1971

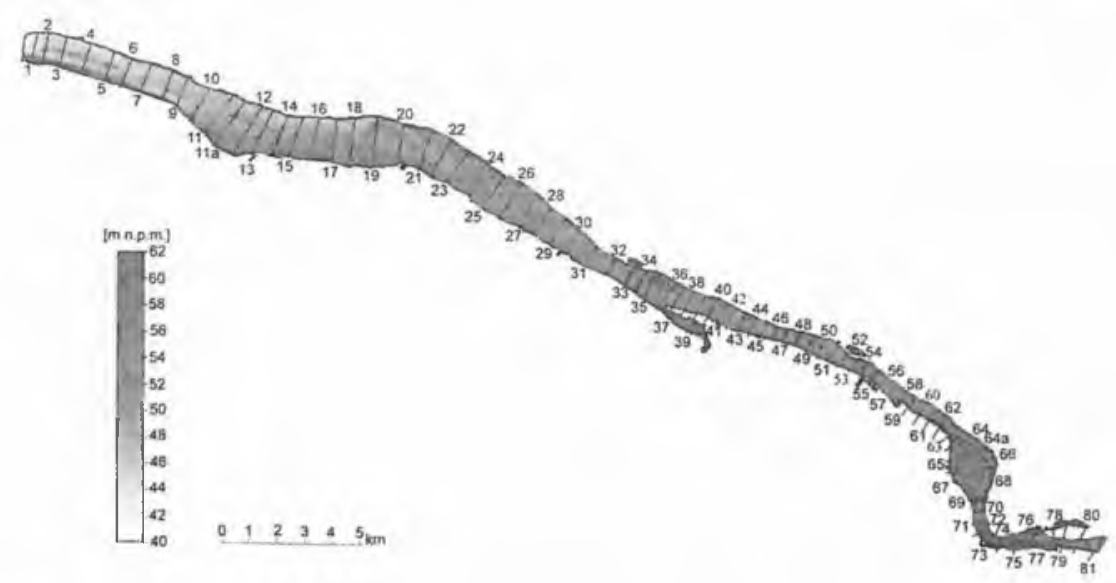

Fig. 2. Ordinates of the bottom of Whocławek Reservoir in 1992

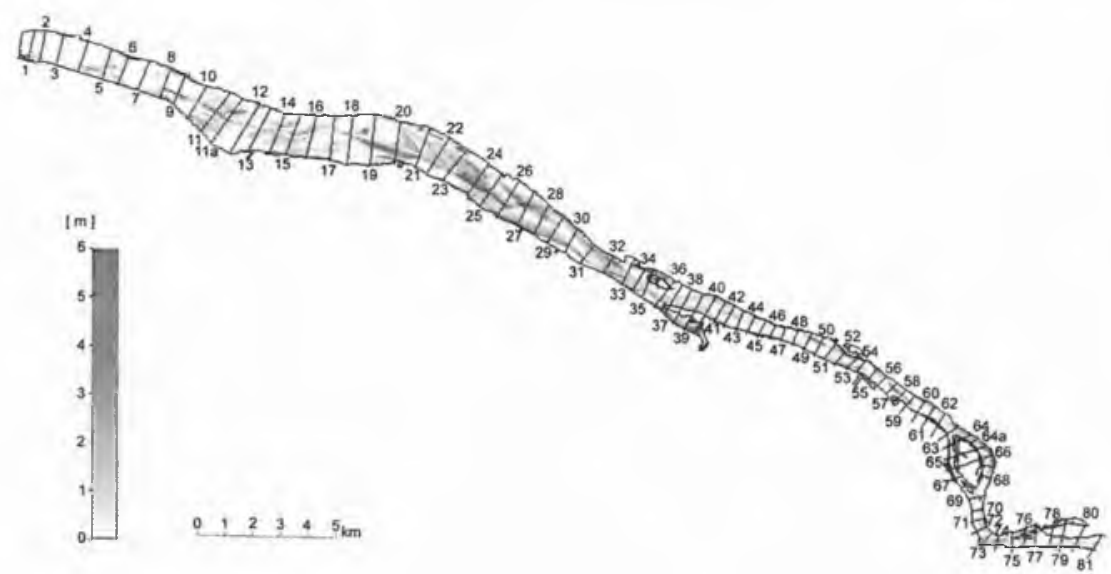

Fig. 3. Accumulation and erosion areas formed in the years 1971-1992 


\section{RESULTS}

Many authors, e.g. (1972,1976), Babiński (2002), Dębski (1939, 1956), Wiśniewski (1972) examined the issue of assessing the volume of the transported river sediments and its accumulation in the reservoir (Tab.1). The results obtained by these authors, however, correspond to different research periods and were based on different methods of calculation, and as such are difficult to compare. They are given in Table 1 below.

Table 1.

Average annual volume of accumulated material in Whocławek Reservoir, as calculated by different authors, in millions

\begin{tabular}{|c|c|c|c|c|}
\hline Author & $\begin{array}{l}\text { Research } \\
\text { period }\end{array}$ & $\begin{array}{l}\text { Type of } \\
\text { material } \\
\text { bedlood }\end{array}$ & $\begin{array}{c}\text { Type of } \\
\text { material } \\
\text { suspended }\end{array}$ & $\begin{array}{l}\text { Total } \\
\text { volume }\end{array}$ \\
\hline Dębski (1939) & forecast & - & - & $1.02 \mathrm{mn} \mathrm{m}^{3}$ \\
\hline Dębski (1956) & . & - & - & $2.51 \mathrm{mn} \mathrm{m}^{3}$ \\
\hline Brański (1972) & $1956-1965$ & - & $\begin{array}{c}0.24 \mathrm{mn} \mathrm{m}^{3^{*}} \\
0.44 \mathrm{mn} \mathrm{t}^{-}\end{array}$ & - \\
\hline Wiśniewski (1972) & - & $0.50 \mathrm{mn} \mathrm{m}^{3}$ & $1.00 \mathrm{mn} \mathrm{m}^{3}$ & - \\
\hline $\begin{array}{l}\text { Brański, Dąbkowski } \\
\text { (1976) }\end{array}$ & - & $\begin{array}{l}0.26 \mathrm{mn} \mathrm{m}^{3 *} \\
0.47 \mathrm{mn} \mathrm{t}^{2}\end{array}$ & - & $\begin{array}{c}0.62 \mathrm{mn} \mathrm{m}^{3^{*}} \\
1.11 \mathrm{mn} \mathrm{t}^{-}\end{array}$ \\
\hline Skibiński (1985) & - & - & - & $\begin{array}{c}1.52 \mathrm{mn} \mathrm{m}{ }^{3} \\
2.24 \mathrm{mn} \mathrm{t}\end{array}$ \\
\hline $\begin{array}{l}\text { Hydroprojekt (1992) } \\
\text { (Sliwinski) }\end{array}$ & $\begin{array}{l}1971-1992 \\
1987-1992 \\
\end{array}$ & - & - & $\begin{array}{l}1.8 \mathrm{mn} \mathrm{m}^{3} \\
2.2 \mathrm{mn} \mathrm{m}^{3}\end{array}$ \\
\hline Babiński (2002) & $\begin{array}{l}1971-1990 \\
1971-1995\end{array}$ & $\begin{array}{l}2.33 \mathrm{mn} \mathrm{t}^{3 *} \\
1.29 \mathrm{mn} \mathrm{m}^{3^{*}} \\
2.2 \mathrm{mn} \mathrm{t}^{3} \\
1.22 \mathrm{mn} \mathrm{m}^{3^{*}}\end{array}$ & $\begin{array}{c}0.17 \mathrm{mn} \mathrm{m}^{3^{*}} \\
0.3 \mathrm{mn} \mathrm{t} \\
- \\
-\end{array}$ & $\begin{array}{c}1.46 \mathrm{mn} \mathrm{m}^{3^{*}} \\
2.63 \mathrm{mn} \mathrm{t} \\
- \\
-\end{array}$ \\
\hline
\end{tabular}

*value obtained from the conversion: $1 \mathrm{~m}^{3}=1.8$ tons

The use of the calculation method described in this study indicates that in the first 13 years since the creation of the reservoir the volume of accumulated materials was 38,1 million $\mathrm{m}^{3}$ (Table 2 ), and the volume of the material eroded from Włoclawek Reservoir - 33.2 million $\mathrm{m}^{3}$. In the next period, 1984 to 1992 , the accumulation volume was 37.6 million $\mathrm{m}^{3}$ (comparable to the previous period) with a substantially reduced erosion at a level of 24.2 million $\mathrm{m}^{3}$. This was probably the result of small average annual discharges, lower than $880 \mathrm{~m}^{3} / \mathrm{s}$, in this period. The flow rates were at a level which did not lead to the erosion of clastic material. Throughout the research period, i.e. in the years 1971-1992, Wlocławek Reservoir retained 51.2 million $\mathrm{m}^{3}$ of river sediments, of which 32.9 million $\mathrm{m}^{3}$ were eroded.

The calculated volume of the eroded material does not take into account the dredging works started in the upper section of the reservoir after 1982; 
Volume of accumulation and erosion in Włocławek Reservoir, by period

\begin{tabular}{|c|c|c|c|}
\hline Period & $1971-1984$ & $\mathbf{1 9 8 4 - 1 9 9 2}$ & $\mathbf{1 9 7 1 - 1 9 9 2}$ \\
\hline $\begin{array}{c}\text { Accumulation } \\
{\left[\text { million } \mathrm{m}^{3}\right]}\end{array}$ & 38.08 & 37.61 & 51.20 \\
\hline $\begin{array}{c}\text { Erosion } \\
{\left[\text { million } \mathrm{m}^{3}\right]}\end{array}$ & 33.19 & 24.18 & 32.88 \\
\hline $\begin{array}{c}\text { Sediments balance } \\
{\left[\text { million } \mathrm{m}^{3}\right]}\end{array}$ & +4.89 & +13.43 & +18.32 \\
\hline $\begin{array}{c}\text { Average annual } \\
\text { accumulation } \\
{\left[\text { [million } \mathrm{m}^{3}\right]}\end{array}$ & +0.38 & +1.68 & +0.87 \\
\hline
\end{tabular}

they are shown in a study published by Dziużyński and Magnuszewski (1998), who used a similar calculation method. The area covered by their research was smaller, and stretched over a section of the Vistula between 618 and 640 kilometres. These calculations indicated that the erosion in 1971-1992 reached a volume of approximately 8 million $\mathrm{m}^{3}$, and in a much shorter period of 1984-1992-8.7 million $\mathrm{m}^{3}$.

In order to balance the volume of the material deposited in Włocławek Reservoir, the volume of the eroded material was deducted from the volume of the accumulated material. The calculations indicate that in the years 1971-1984 the reservoir retained 4.9 million $\mathrm{m}^{3}$ of clastic material, against as much as 13.4 million $\mathrm{m}^{3}$ in 1984-1992 (Table 2). Expressed as average annual accumulation, this gives the value of +0.4 million $\mathrm{m}^{3}$ and +1.7 million $\mathrm{m}^{3}$, respectively. Such a high average annual accumulation in the latter period was caused by a smaller volume of the eroded material. In the period 1971-1992, the result of the balance was +18.3 million $\mathrm{m}^{3}$, and +37.9 million $\mathrm{m}^{3}$ in "Hydroprojekt"'s calculation. These values, transposed into average annual accumulation, are equal to 0.9 million $\mathrm{m}^{3}$ and 1.8 million $\mathrm{m}^{3}$. Such a discrepancy of the results is a consequence of using two different methods of calculating volume. "Hydroprojekt" used a method based on balancing within the transversal cross-sections, while the method discussed in this study involved the development of a digital terrain model and calculation of its quantitative characteristics.

Also, the size of areas covered by erosion and accumulation were calculated, and those where in the different periods accumulation was equal to erosion. The results are provided in Table 3. 
Table 3.

The area of Włocławek Reservoir subject to accumulation and erosion processes, by period

\begin{tabular}{|c|c|c|c|}
\hline Process & $1971-1984$ & $1984-1992$ & $1971-1992$ \\
\hline $\begin{array}{c}\text { Accumulation } \\
\text { [thousand m²] }\end{array}$ & 331.12 & 337.00 & 362.55 \\
\hline $\begin{array}{c}\text { Erosion } \\
\text { [thousand m²] }\end{array}$ & 265.22 & 250.20 & 250.80 \\
\hline $\begin{array}{c}\text { Equilibrium } \\
\text { [thousand m²] }\end{array}$ & 94.85 & 104.00 & 77.85 \\
\hline $\begin{array}{c}\text { Ratio of accumulation } \\
\text { area to erosion area }\end{array}$ & 1.25 & 1.35 & 1.45 \\
\hline
\end{tabular}

These results confirm that despite the intense dredging works, sediment accumulation is the dominant process occurring in Włocławek Reservoir.

\section{CONCLUSIONS}

Owing to erosion and sedimentation processes, the shape of the bottom of Whocławek Reservoir is undergoing constant changes. The dynamics of those changes mainly depend on hydrological conditions, and, to a lesser extent, on abrasion and sliding along the banks of the reservoir. The systematic surveys of the progress of sedimentation and erosion in the reservoir have shown than in 1971-1992, large amounts of river sediments were deposited in the reservoir. Its volume is assessed at approximately 18.3 million $\mathrm{m}^{3}$, which corresponds to about 0.87 million $\mathrm{m}^{3}$ of sediments per year. This also reveals the fact that accumulation is the dominant process in the balance of the sediments, and this result is similar to the earlier calculations. Over the past 21 years, the loss in total storage capacity owing to sedimentation processes reached about $4.5 \%$. This means that if a similar rate of siltation is maintained, Włocławek Reservoir will continue to serve economic functions for another 400 years.

This method used to describe sedimentation processes in Włocławek Reservoir allowed for an easy interpretation of the obtained results and for performing relatively accurate calculations of the sediments balance. 


\section{REFERENCES}

Ankiersztajn I., 2002. Budowa stopnia wodnego w Nieszawie-Ciechocinku. Koncepcja programowo-przestrzenna, część I [Construction of the Barrage in Nieszawa-Ciechocinek. A Programme and Spatial Perspective, Part I; in Polish], The Barrage in Wloctawek. Status Quo and Effects of Operation, Vol. II, Hydroprojekt Warszawa sp. z o. o., Warszawa.

Babiński Z., Grześ M., 1995, Monografia hydrologiczna zbiornika stopnia wodnego Whoclawek [Hydrological Monography of the Wloclawek Barrage Reservoir; in Polish], Prace Geograficzne No. 30, IGiPZ PAN, Warszawa.

B a binski Z., 2002, Wptyw zapór na procesy korytowe rzek aluwialnych [Impact of Dams on Bed Processes in Alluvial Rivers; in Polish], Akademia Bydgoska, Bydgoszcz.

Dziurzyński T., Magnuszewski A., 1998, Nowa metoda zobrazowania i obliczeń tempa sedymentacji $w$ Jeziorze Whoclawskim za pomoca systemu geoinformacyjnego [A New Method of Visualization and Calculating the Sedimentation Rate in Wloclawek Reservoir Using GIS; in Polish], Gospodarka Wodna, No 6.

Glodek J., 1985, Jeziora zaporowe świata [Barrage Lakes in the World, in Polish], PWN, Warszawa.

Dębski K., 1939, O transporcie i osadzaniu aluwiów [On Transport and Sedimentation of Alluvial Deposits; in Polish], Gospodarka Wodna, No 2.

Dębski K., 1956, Gdzie leży bezpieczeństwo Gdańska i delty Wisły [What Controls the Security of Gdańsk and the Delta of the Vistula; in Polish], Gospodarka Wodna, No 6.

Brańs k i J., 1972, Bilans transportu rumowiska unoszonego wzdluż biegu Wisły [Balance of the Sediments Carried Down the Vistula, in Polish], Gospodarka Wodna, No 3.

Brański J., Dąbkowski S.L., 1976, Uwagi o prognozowaniu zamulania zbiorników wodnych na rzekach nizinnych [Remarks on Forecasting Siltation in Water Reservoirs in Lowland Rivers; in Polish], Archiwum Hydrotechniki, 3.

Skibiński J., 1985, Charakterystyka morfologiczna Wisły na odcinku Modlin-Włocławek oraz zmiany powstałe w ukształtowaniu dna w wyniku spiętrzenia wody w Zbiorniku Whoclawskim [The Morphological Characteristics of the Vistula Between Modlin and Wlocławek and Changes in the River Bottom Caused by Damming Water in the Wlocławek Reservoir; in Polish], M a jew sk i W. (ed.) Powódź zatorowa na Wiśle w rejonie Zbiornika Whoctawek $w$ zimie $1982 \mathrm{r}$. [The Vistula Ice Jam Flood near the Wloclawek Reservoir in the Winter of 1982, in Polish], Wydawnictwo Geologiczne, Warszawa.

Śliwiński W., (ed.), 1992, Procesy sedymentacyjne $w$ zbiorniku Wtoclawek [Sedimentation Processes in the Whoclawek Reservoir; in Polish], Hydroprojekt Warszawa-Office in Wlocławek (materials of the Regional Water Management Administration, Warszawa).

Wiśn i e w ski B., 1972, Ilość rumowiska unoszonego i wleczonego w rzekach polskich [Volume of Sediments Floated and Carried by Polish Rivers, in Polish]; Gospodarka Wodna, No 10-11.

Translated by Dorota Szmajda 